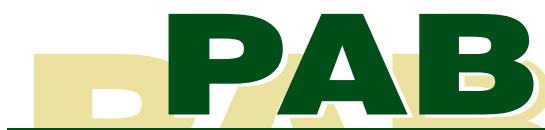

Pesquisa Agropecuária Brasileira

ISSN 1678-3921

Journal homepage: www.embrapa.br/pab

For manuscript submission and journal contents, access: www.scielo.br/pab

Ana Paula Del Medico ${ }^{(1 凶)}(3$,

Victoria Guadalupe Cabodevila(1)

María Susana Vitelleschi(2) and

Guillermo Raúl Pratta ${ }^{(1)}$

(1) Universidad Nacional de Rosario, Facultad de Ciencias Agrarias, Instituto de Investigaciones en Ciencias Agrarias de Rosario, Consejo Nacional de Investigaciones Científicas y Técnicas - Cátedra de Genética, Campo Experimental Villarino, Zavalla, CP 2125 Santa Fe, Argentina.

E-mail: delmedico@iicar-conicet.gob.ar, victoria.cabodevila@unr.edu.ar, gpratta@unr.edu.ar

(2) Universidad Nacional de Rosario, Facultad de Ciencias Económicas y Estadística, Instituto de Investigaciones Teóricas y Aplicadas de la Escuela de Estadística, Bv. Oroño 1261, Rosario CP 2000

Santa Fe, Argentina.

E-mail: mvitelle@fcecon.unr.edu.ar

$凶$ Corresponding author

Received

August 24, 2017

Accepted

March 30, 2018

How to cite

DEL MEDICO, A.P.; CABODEVILA, V.G.; VITELLESCHI, M.S.; PRATTA, G.R. Multivariate estimate of heritability for quality traits in tomatoes by the multiple factor analysis Pesquisa Agropecuária Brasileira, v. 54 , e00064, 2019. DOI: https://doi.org/10.1590/ S1678-3921.pab2019.v54.00064.

\section{Multivariate estimate of heritability for quality traits in tomatoes by the multiple factor analysis}

\begin{abstract}
The objective of this work was to evaluate a multiple factor analysis approach to estimate heritability for quality traits in tomatoes (Solanum lycopersicum), taking as a reference the values of heritability obtained through the classical method offspring-parent regression. A total of $18 \mathrm{~F}_{3}$ tomato families originated from the selfing of 18 individuals from a second-cycle hybrid were evaluated. In both generations, ten quantitative traits related to fruit quality were assessed. The multiple factor analysis showed that some of the evaluated traits performed differently and others similarly between generations. Heritability is low or null for some traits, such as shelf life and reflectance percentage, and high for others, as weight and shape. That analysis also enables the study of the global connection between both generations through the RV $\left(\mathrm{F}_{3}, \mathrm{~F}_{2}\right)$ coefficient, which measures the correlation between two matrix configurations. RV was 0.503 and may be associated with the general heritability of all data. The multiple factor analysis is a valid multivariate technique to evaluate heritability for quality traits in tomatoes.
\end{abstract}

Index terms: Solanum lycopersicum, multiple factor analysis, quantitative traits.

\section{Estimativa multivariada da herdabilidade para características de qualidade de tomates por meio da análise de fatores múltiplos}

Resumo - O objetivo deste trabalho foi avaliar uma abordagem de análise de fator múltiplo para estimar a herdabilidade de características de qualidade em tomates (Solanum lycopersicum), tendo como referência os valores de herdabilidade obtidos por meio do método clássico de regressão parental descendente. Foi avaliado um total de 18 famílias de tomate $F_{3}$ originadas do autocruzamento de 18 indivíduos de um híbrido de segundo ciclo. Em ambas as gerações, foram avaliadas dez características quantitativas relacionadas à qualidade da fruta. A análise de fator múltiplo mostrou que algumas das características avaliadas apresentaram desempenho diferente e outras semelhante entre as gerações. A herdabilidade é baixa ou nula para algumas characterísticas, como vida útil e percentagem de refletância, e alta para outras, como peso e forma. Essa análise também permite o estudo da conexão global entre ambas as gerações por meio do coeficiente $\mathrm{RV}\left(\mathrm{F}_{3}, \mathrm{~F}_{2}\right)$, que mede a correlação entre duas configurações de matriz. $\mathrm{O} R V$ foi 0,503 e pode estar associado à herdabilidade geral de todos os dados. A análise de fatores múltiplos é uma técnica multivariada válida para avaliar a herdabilidade de características de qualidade em tomates.

Termos para indexação: Solanum lycopersicum, análise de fatores múltiplos, características quantitativas. 


\section{Introduction}

Tomato (Solanum spp.) is one of the most relevant productions of the horticultural sector in Argentina (Cabodevila et al., 2017b).

In recent years, consumers have become more selective and are demanding healthier and more nutritive food, which has led to a greater effort to obtain fruits and vegetables with higher nutritional values (Pratta et al., 2011). Therefore, in the past decades, especially for fresh consumption, several "late ripeness" mutant genes were introgressed to highly productive tomato varieties in order to obtain fruit with a long shelf life (Rodríguez et al., 2010). However, those mutant genes usually cause pleiotropic effects that reduce fruit quality, affecting important component traits such as flavor, color, and texture (Rodríguez et al., 2010).

According to Pereira da Costa et al. (2009), it is possible to cross Solanum lycopersicum L. to wild tomato germplasm to improve not only fruit quality but also shelf life. In the last decade, the Caimanta cultivar (Estación Experimental Agropecuaria of Instituto Nacional de Tecnología Agropecuaria, Cerrillos, Salta, Argentina) of the cultivated Argentinean tomato (S. lycopersicum) was crossed with the wild species Solanum pimpinellifolium L., accession LA 722 (Tomato Genetic Resources Center, University of California, Davis, CA, USA) (Rodríguez et al., 2006a). After six cycles of recombination and antagonistdivergent selection for fruit weight and shelf life, 18 recombinant inbred lines (RILs) were obtained from this interspecific cross (Rodríguez et al., 2006a).

By crossing selected RILs, second-cycle hybrids (SCH) are obtained (Ipsilandis et al., 2006; Pereira da Costa et al., 2016). Cabodevila et al. (2017a) evaluated a $\mathrm{F}_{2}$ population of 69 individuals that was generated by selfing the $\mathrm{SCH}\left(\mathrm{F}_{1}\right.$ ToUNR18 $\mathrm{x}$ ToUNR1) obtained by Marchionni Basté et al. (2010) when crossing some of the previously mentioned tomato RILs. In this segregating generation, 18 individuals were selected (Cabodevila et al., 2017a) to obtain $18 \mathrm{~F}_{3}$ families.

In these families, heritability estimates for traits of agronomic interest allow defining the best breeding strategy to improve quantitative traits in the population. One of the methods used for the estimation of narrow-sense heritability is the offspring-parent regression, which is considered univariate since it connects the values measured for a single quantitative trait in two related generations (Mariotti \& Collavino,
2014). However, in order to increase the genetic gain for complex traits, such as fruit quality, it would be appropriate to estimate a joint value of heritability that simultaneously includes all or at least a great number of its components (Pratta et al., 2010). Although there are several papers on measuring multivariate diversity (Rodríguez et al., 2005; Ayalew et al., 2011; Ganopoulos et al., 2015), there is still the need for new methods to calculate multivariate heritability. The present study is the first known report in which a multivariate analysis is used to estimate a joint value of heritability for tomato families.

In this context and due to its ability to detect associations among multidimensional quantitative data in various groups of data, one of the most appropriate methods to estimate multivariate heritability is the multiple factor analysis (Pagès, 2017).

The objective of this work was to evaluate a multiple factor analysis approach to estimate heritability for quality traits in tomatoes, taking as a reference the values of heritability obtained through the classical method offspring-parent regression.

\section{Materials and Methods}

The plant material consisted of 18 individuals (parent genotypes) from the $\mathrm{F}_{2}$ generation of the SCH ToUNR18 $\mathrm{x}$ ToUNR 1 and of the corresponding 18 families of the $\mathrm{F}_{3}$ generation (offspring genotypes) obtained by selfing. The SCH ToUNR18 $x$ ToUNR1 is the cross of two selected RILs derived from an interspecific tomato cross carried out by Rodríguez et al. (2006a), and the complete $\mathrm{F}_{2}$ generation was evaluated by Cabodevila et al. (2017a); the 18 individuals used in the present study were selected as parental genotypes according to their molecular and phenotypic diversity. Both the $F_{2}$ and $F_{3}$ generations were assessed under greenhouse conditions at Universidad Nacional de Rosario, Rosario, Argentina $\left(33^{\circ} 01^{\prime} 52.1^{\prime \prime} \mathrm{S}, 60^{\circ} 53^{\prime} 23.3^{\prime \prime} \mathrm{W}\right)$, in two crop cycles. In 2011/2012, a total of $69 \mathrm{~F}_{2}$ individuals were evaluated in a completely randomized design, and, in 2014/2015, the $18 \mathrm{~F}_{3}$ families were analyzed; each family was composed by 11 plants, which were sown in a randomized plot design, with two plots of five and six plants per family, respectively.

As in Mahuad et al. (2013), ten quantitative traits were evaluated: five in fruits harvested at the breaker stage, when carotenoid accumulation becomes visible, and five in fruits harvested at the red-ripe stage, with

Pesq. agropec. bras., Brasília, v.54, e00064, 2019

DOI: 10.1590/S1678-3921.pab2019.v54.00064 
approximately $90 \%$ red surface. At the breaker stage, the following traits were measured in ten fruits per plant: weight, in grams; diameter, in centimeters; height, in centimeters; shape, as the ratio between height and diameter; and shelf life, as the number of days from harvest until the fruit stored at $25 \pm 3^{\circ} \mathrm{C}$ loses commercial value due to, for instance, excessive softening. In fruits at the red-ripe stage, the studied traits were: soluble solids content, in Brix degrees, as the percentage of fructose and glucose in fruit juice; $\mathrm{pH}$ of fruit juice; and firmness on two opposite equatorial sides, determined by the Shore A digital firmness tester Durofel DFT 100 (Agrosta, Serqueux, France), with a $0.10 \mathrm{~cm}^{2}$ cap. In addition, fruit color was analyzed using: the $\mathrm{a} / \mathrm{b}$ ratio or Chroma index, where "a" and "b" are the absorbance at 540 and $675 \mathrm{~nm}$ wavelengths, respectively; and the $\mathrm{L}$ value or reflectance percentage, where $\mathrm{L}$ is the parameter from +100 for white up to 0 for black. The values of $a, b$, and $\mathrm{L}$ were obtained with the CR-400 Chroma Meter (Konica Minolta Sensing Americas, Inc., Ramsey, NJ, USA). Color parameters and firmness were determined in five intact fruits per plant, whereas soluble solids content and $\mathrm{pH}$ were measured in the juice obtained by homogenizing a variable number of three up to eight fruits per plant, depending on fruit size. The values of the presented and analyzed traits are the mean value of each individual in the $\mathrm{F}_{2}$ generation (parental genotypes) and of each family in the $F_{3}$ generation (offspring genotypes), calculated by averaging the mean value of each plant within the family.

In order to estimate multivariate heritability, the multiple factor analysis (MFA) was performed in the R software (R Core Team, 2017). The MFA (Escofier \& Pagès, 1992, 1994) provides a global measure of the relationship between groups, based on the RV coefficient, which allows quantifying the association between two data tables, using values between 0 and 1 . If the configurations are orthogonal, $\mathrm{RV}=0$, indicating that there is no correspondence or covariance among both generations for the evaluated traits; if the distance between configurations is null, $R V=1$, indicating that there is a complete correspondence or covariance among both generations for the studied traits. Consequently, RV is proposed as the multivariate estimate of a joint heritability for a given complex trait, in this case, fruit quality.
The three ways of the data matrix are: 18 tomato genotypes, 10 traits related to tomato quality, and 2 generations ( $F_{2}$ as parents and $F_{3}$ as offspring). As a reference to validate this new methodological approach for calculating a joint value of heritability, the classic offspring-parent regression (OPR) method was applied to each individual trait (Mariotti \& Collavino, 2014).

\section{Results and Discussion}

The heritability estimates by the univariate classic OPR analyses for shelf life, $\mathrm{L}, \mathrm{a} / \mathrm{b}$ ratio, firmness, and soluble solids were null because the regression coefficients were not significant (Table 1). Consequently, additive variance is not relevant in the genetic determination of these traits (Mariotti \& Collavino, 2014). However, weight, height, diameter, and shape presented intermediate heritability values, whereas $\mathrm{pH}$ had low values, according to Rodríguez et al. (2008). For these authors, heritability values below 0.25 are considered low; between 0.25 and 0.50 , intermediate; and greater than 0.50 , high. Therefore, additive variance is significant for genetic variation underlying the five latter traits; however, only the first four could be responsive to artificial selection (Mariotti \& Collavino, 2014). These results are in partial agreement with those of Rodríguez et al. (2006b), Pereira da Costa et al. (2009), and Pratta et al. (2011), who reported a variation in heritability values for the same traits, which is possibly due to the different genetic structure of the evaluated tomato populations.

In the estimate of multivariate heritability obtained by the MFA, the first global axis collected a percentage

Table 1. Heritability values estimated by the offspring $\left(\mathrm{F}_{3}\right)$-parent $\left(\mathrm{F}_{2}\right)$ regression, standard error, and $\mathrm{p}$-values for quality traits in tomatoes (Solanum lycopersicum).

\begin{tabular}{lccc}
\hline Traits & Heritability & Standard error & p-value \\
\hline Weight & 0.33 & 0.11 & 0.0005 \\
Height & 0.46 & 0.09 & $<0.0001$ \\
Diameter & 0.41 & 0.16 & 0.002 \\
Shape & 0.43 & 0.12 & 0.0001 \\
Shelf life & 0.00 & 0.00 & 0.9161 \\
L & 0.00 & 0.00 & 0.6909 \\
a/b ratio & 0.00 & 0.00 & 0.277 \\
Soluble solids & 0.00 & 0.00 & 0.4838 \\
pH & 0.11 & 0.06 & 0.0145 \\
Firmness & 0.00 & 0.00 & 0.1927 \\
\hline
\end{tabular}


of $33.67 \%$ total variation, and the second one of $17.31 \%$ (Table 2). These results indicate that $51 \%$ total variation is explained by the two first global axes of the MFA, suggesting a good fit between the output of the analyses and the input data (Pagès, 2017).

The factorial plane formed by the two first global axes was considered for the analysis because its composition differentiates the tomato genotypes according to the quality attributes of the main tomato fruit. As in the standard principal component analysis, the variable loadings represents the correlation between the original variables and the global factor scores (Table 3); these loadings are plotted in Figure 1 along with the "circles of correlation".

The first global axis highlights the characterization of tomato size, and the variables height ( 0.94 for both generations), weight ( 0.87 for both generations), and diameter $\left(0.83\right.$ for $F_{3}$ and 0.85 for $\left.F_{2}\right)$ are the ones that contribute the most to the composition of the trait (Table 3). Therefore, the genotypes in the axis left end show the lowest values for height, weight, and diameter; the opposite is observed in the axis right end. The variables that contribute the most to the formation of the second axis are the $\mathrm{a} / \mathrm{b}$ ratio $(0.66)$, $\mathrm{L}(0.69)$, and shelf life (0.89) for the $\mathrm{F}_{3}$ generation and firmness $(0.68)$ for the $F_{2}$ generation; the first trait contributes negatively and the other three, positively. Therefore, at the bottom end of the second axis, are the tomato genotypes with lower firmness and shelf life, a high a/b ratio, low brightness, and low L. On the other side, at the top end, are the tomato genotypes with high external quality. In the context of estimating multivariate heritability, the composition of the first global axis was similar for the traits in the $F_{2}$ and $F_{3}$ generations, which would evidence a good correspondence between parents and offspring.

The configuration of the variables is represented on the first two global axes, i.e., Dim 1 and Dim 2 (Figure 1). It should be noted that some vectors that

Table 2. Eigenvalues associated with the two first axes of the multiple factor analysis to estimate quality traits in tomatoes (Solanum lycopersicum).

\begin{tabular}{lcc}
\hline Axes & Eigenvalues & Percentage \\
\hline 1 & 1.78 & 33.67 \\
2 & 0.92 & 17.31 \\
\hline
\end{tabular}

represent the same variable in both generations have small angles and similar lengths. From a multivariate viewpoint, this finding could indicate that such variables have high heritability, similarly to the traits weight, height, diameter, and shape. In fact, Rodríguez et al. (2010) and Pratta et al. (2011) also reported a high heritability for the same traits. Considering the previous inferences about the length of each trait vector and its angles between the $F_{2}$ and $F_{3}$ generations, the heritability of soluble solids and the $\mathrm{a} / \mathrm{b}$ ratio would be low since they have different vector lengths but small angles. In the case of the variables $L$ and shelf life, due to the largest angles between both generations, their behavior would be less similar than that of the rest, indicating low or null heritability. These observations correspond to the heritability values estimated by the OPR (Table 1) and are in alignment with the previous report of Pratta et al. (2011). For firmness, heritability appears to be moderate and, despite the OPR, it was

Table 3. Loadings for the two global axes for quantitative traits in the $F_{2}$ and $F_{3}$ generations of tomato (Solanum lycopersicum).

\begin{tabular}{lccc}
\hline Traits & \multicolumn{2}{c}{ Loadings } \\
\cline { 2 - 3 } & Dim 1 & Dim 2 \\
\hline & & $\mathrm{F}_{3}$ generation \\
a/b ratio & -0.17 & & -0.66 \\
Firmness & -0.21 & 0.55 \\
$\mathrm{~L}$ & -0.46 & 0.69 \\
$\mathrm{pH}$ & 0.63 & -0.47 \\
Soluble solids & -0.54 & -0.42 \\
Weight & 0.87 & 0.18 \\
Diameter & 0.83 & 0.29 \\
Height & 0.94 & 0.06 \\
Shape & 0.50 & -0.41 \\
Shelf life & 0.20 & 0.89 \\
\hline & & $\mathrm{F}_{2}$ generation \\
a/b ratio & -0.19 & \\
Firmness & -0.26 & -0.13 \\
L & -0.21 & 0.68 \\
pH & 0.48 & -0.28 \\
Soluble solids & -0.29 & -0.34 \\
Weight & 0.87 & -0.08 \\
Diameter & 0.85 & 0.15 \\
Height & 0.94 & 0.24 \\
Shape & 0.47 & 0.04 \\
Shelf life & 0.30 & -0.35 \\
\hline
\end{tabular}


not significant. However, the correlations between the traits inside each generation can skew the results for certain variables, whose variability can be overstated in the data set (Pagès, 2017).

The paths of each genotype, in both generations, are represented by three points (Figure 2). The points in the middle correspond to the consensus configurations and those at the extreme ends, to the relative positions of the genotypes in each generation (Pagès, 2017). It can be observed that the paths of genotypes II58, II66, IV61, and IV65 are quite wide, indicating that their traits differ from generation to generation. The II58 genotype differs in external fruit quality; II66 and IV61, in fruit size; and IV65 in size and quality. However, genotypes VIII9, VIII12, I50, VI42, and I89 have similar traits in both generations. The similarity between an individual and its offspring may be an estimator of the reproductive value for that individual (Laird \& Lange, 2011). Therefore, the position of the genotypes from the $F_{2}$ and $F_{3}$ generations (Figure 2) evidences that some individuals are more similar to their offspring than others in the multivariate space defined by the fruit quality traits evaluated. This suggests that there are differences in their reproductive values, evaluated in a multivariate way for the data set. The ratio between additive variability and phenotypic

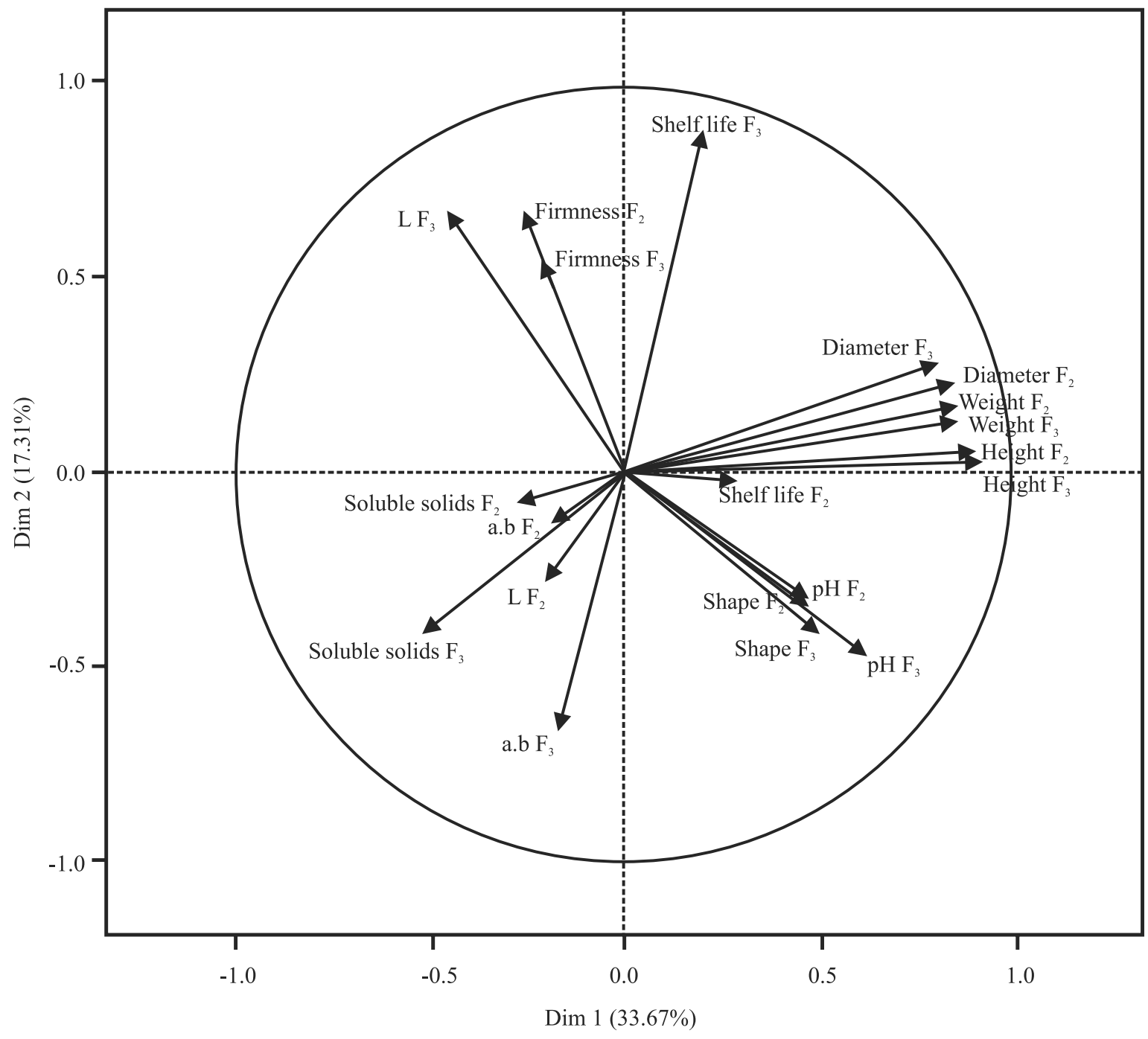

Figure 1. Representation of the variables in the $\mathrm{F}_{2}$ and $\mathrm{F}_{3}$ generations of tomato (Solanum lycopersicum) according to their loadings for the first two global axes. 
variability refers to the classic concept of narrow-sense heritability (Mariotti \& Collavino, 2014); this is an indicative that there should be multivariate heritability for fruit quality and that estimation could be carried out in the space of the generations, that is, in the conditions under which the individuals (genotypes) were evaluated.

Finally, when comparing the $\mathrm{F}_{2}$ and $\mathrm{F}_{3}$ generations, no significant differences were observed on the first global axis - greatly associated with fruit weight, height, and diameter -, indicating similar size (Figure 3). In fact, this is an expected result according to the high heritability presented by those traits. However, both generations show differences on the second axis, which is highly related to the $\mathrm{a} / \mathrm{b}$ ratio,
$\mathrm{L}$, and shelf life. This indicates that the $\mathrm{F}_{2}$ and $\mathrm{F}_{3}$ generations vary as to external fruit quality, which is defined by the traits that have low or null heritability.

The RV coefficient, which allows quantifying the association between both generations according to the multivariate variation for the assessed fruit quality traits, was 0.503 . This intermediate value indicates that both generations present a structure with some similarities and differences. In other words, a moderate correspondence or covariance was verified for the data set analyzed in both generations, and this value can be interpreted as the joint heritability of the data set. This estimate would allow performing an objective and multi-trait selection to continue with new cycles of selfing, and, consequently, to obtain a joint genetic gain

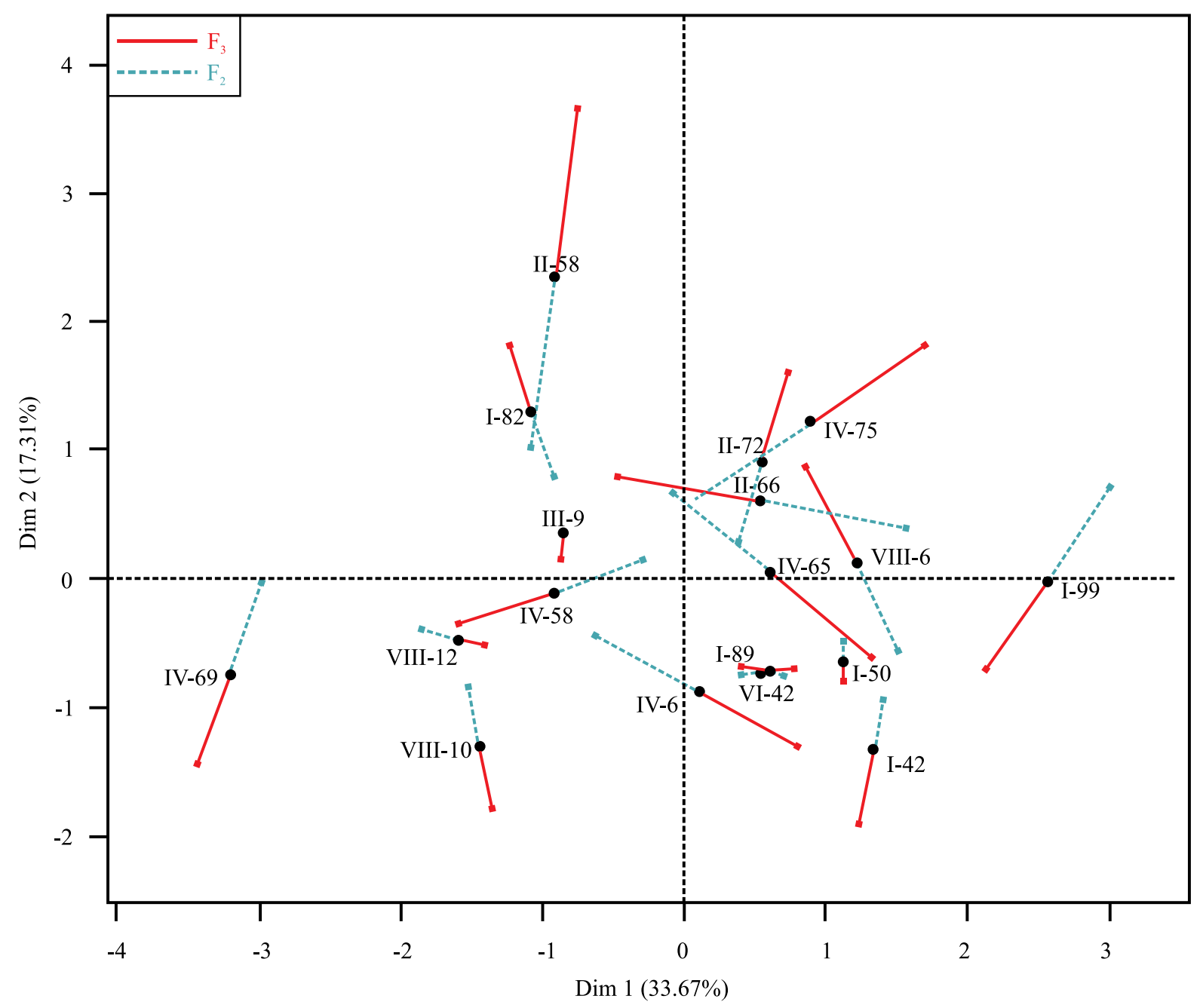

Figure 2. Projection of the average and partial tomato (Solanum lycopersicum) genotypes on the two first global axes. 
in the quality components of the fruit. This response depends on the contribution of each of the components to total phenotypic variability, measured by the first two global axes, and to multivariate heritability, whose magnitude is given by the RV coefficient affected by $2 / 3$, which is usual for selfed crops when estimation is carried out with the $\mathrm{F}_{3}$ and $\mathrm{F}_{2}$ generations (Mariotti \& Collavino, 2014). If a satisfactory response is obtained, a reduction in the additive genetic variation is expected with each cycle of selection; this estimated value is valid for a limited number of generations, i.e., six or seven, depending on the differential selection used. It should be pointed out that this also happens with the heritability estimates obtained conventionally (Laird \& Lange, 2011).

Therefore, the multivariate estimate of heritability could become an analytic criterion with statistical support, as well as a breeding alternative to tandem selection, which is time consuming, and to the selection index construction, which requires a combination of objective and subjective criteria (Mariotti \& Collavino, 2014).

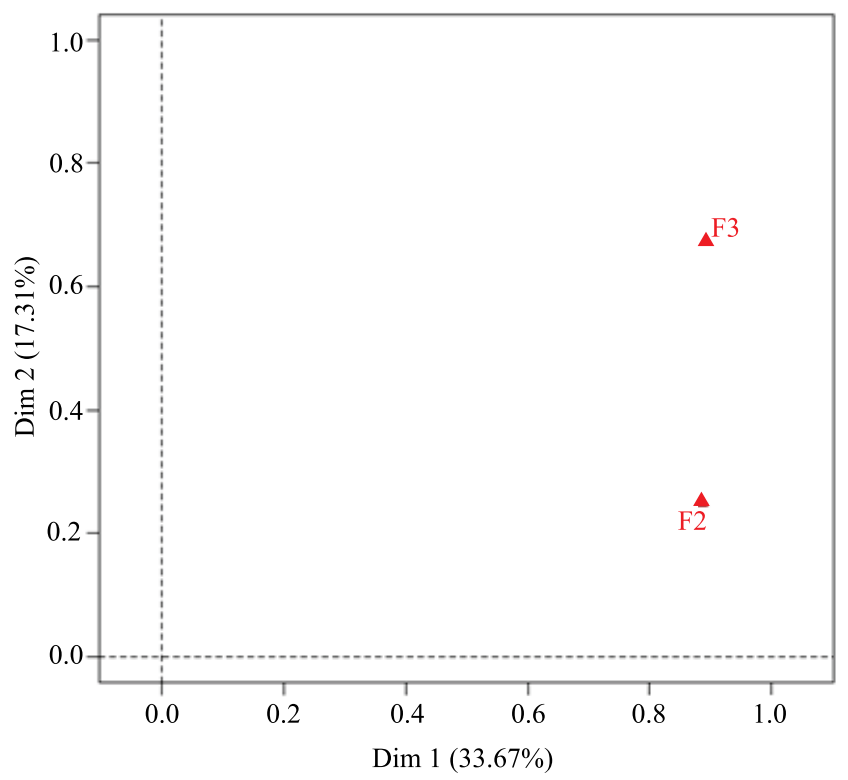

Figure 3. Representation of the $\mathrm{F}_{2}$ and $\mathrm{F}_{3}$ generations of tomato (Solanum lycopersicum) on the first two global axes.

\section{Conclusion}

The multiple factor analysis is an efficient statistical multivariate technique to estimate a joint value of heritability for fruit quality traits in tomatoes (Solanum lycopersicum).

\section{Acknowledgments}

To Agencia Nacional de Promócion Científica y Tecnológica (ANPCyT), for grant PICT 2014-3181.

\section{References}

AYALEW, H.; GENET, T.; DESSALEGN, T.; WONDALE, L. Multivariate diversity, heritability and genetic advance in Tef landraces in Ethiopia. African Crop Science Journal, v.19, p.201-212, 2011.

CABODEVIlA, V.G.; CACCHIARELli, P.; PRATTA, G.R. Identificación de QTL en las generaciones segregantes de un híbrido de segundo ciclo de tomate. Revista de la Facultad de Ciencias Agrarias UNCuyo, v.42, p.1-18, $2017 \mathrm{a}$.

CABODEVILA, V.G.; PICARDI, L.A.; PRATTA, G.R. A multivariate approach to explore the genetic variability in the F2 segregating population of a tomato second cycle hybrid. Journal of Basic and Applied Genetics, v.28, p.7-18, $2017 \mathrm{~b}$.

ESCOFIER, B.; PAGÈS, J. Análisis factoriales simples y múltiples: objetivos, métodos e interpretación. Bilbao: Universidad del País Vasco, 1992. 286p.

ESCOFIER, B.; PAGÈS, J. Multiple factor analysis (AFMULT package). Computational Statistics \& Data Analysis, v.18, p.121140, 1994. DOI: https://doi.org/10.1016/0167-9473(94)90135-X.

GANOPOULOS, I.; MOYSIADIS, T.; XANTHOPOULOU, A.; GANOPOULOU, M.; AVRAMIDOU, E.; ARAVANOPOULOS, F.A.; TANI, E.; MADESIS, P.; TSAFTARIS, A.; KAZANTZIS, K. Diversity of morpho-physiological traits in worldwide sweet cherry cultivars of GeneBank collection using multivariate analysis. Scientia Horticulturae, v.197, p.381-391, 2015. DOI: https://doi.org/10.1016/j.scienta.2015.09.061.

IPSILANDIS, C.G.; TOKATLIDIS, I.S.; VAFIAS, B.; STEFANIS, D. Criteria for developing second-cycle hybrids in maize. Asian Journal of Plant Sciences, v.5, p.680-685, 2006.

LAIRD, N.M.; LANGE, C. The fundamentals of modern statistical genetics. New York: Springer-Verlag, 2011. DOI: 10.1007/978-1-4419-7338-2.

MAHUAD, S.L.; PRATTA G.R.; RODRIGUEZ, G.R.; ZORZOLI, R.; PICARDI, L.A. Preservation of Solanum pimpinellifolium genomic fragments in recombinant genotypes improved the fruit quality of tomato. Journal of Genetics, v.92, p.195-203, 2013. DOI: https://doi.org/10.1007/s12041-013-0245-z.

MARCHIONNI BASTÉ, E.; LIBERATTI, D.R.; MAHUAD, S.L.; RODRIGUEZ, G.R.; PRATTA, G.R.; ZORZOLI, R.; PICARDI, L.A. Diallel analysis for fruit traits among tomato 
recombinant inbred lines derived from an interspecific cross Solanum lycopersicum x S. pimpinellifolium. Journal of Applied Horticulture, v.12, p.21-25, 2010.

MARIOTTI, J.A.; COLLAVINO, N.G. Los caracteres cuantitativos en la mejora genética de los cultivos. [Buenos Aires]: Orientación Gráfica, 2014.

PAGÈS, J. Multiple factor analysis by example using R. Boca Raton: CRC Press, 2017.

PEREIRA DA COSTA, J.H.; MARTÍNEZ, V.A.; RODRÍGUEZ, G.R.; PRATTA, G.R.; ZORZOLI, R. Influencia de genes exóticos sobre la vida en estantería y el peso del fruto de tomate. Agriscientia, v.26, p.7-13, 2009.

PEREIRA DA COSTA, J.H.; RODRÍGUEZ, G.R.; LIBERATTI, D.R.; MAHUAD, S.L.; MARCHIONNI BASTÉ, E.; PICARDI, L.A.; ZORZOLI, R.; PRATTA, G.R. Tomato second cycle hybrids as a source of genetic variability for fruit quality traits. Crop Breeding and Applied Biotechnology, v.16, p.289-297, 2016. DOI: http://dx.doi.org/10.1590/1984-70332016v16n4a44.

PRATTA, G.R.; RODRIGUEZ, G.R.; ZORZOLI, R.; VALLE, E.M.; PICARDI, L.A. Phenotypic and molecular characterization of selected tomato recombinant inbred lines derived from a cross Solanum lycopersicum x S. pimpinellifolium. Journal of Genetics, v.90, p.229-237, 2011.

PRATTA, N.N.; QUAGLINO, M.; RODRÍGUEZ, G.R.; ZORZOLI, R.; PRATTA, G.R. A multivariate approach to the proteomics of tomato fruit ripening. Genes, Genomes and Genomics, v.4, p.48-51, 2010. Special Issue 1.
R CORE TEAM. R: a language and environment for statistical computing. Vienna: R Foundation for Statistical Computing, 2017. Available at: $<$ http://cran.r-project.org $>$. Accessed on: Accessed on: Aug. 222017.

RODRÍGUEZ, G.; PRATTA, G.; ZORZOLI, R.; PICARDI, L.A. Caracterización de la generación segregante de un híbrido de tomate con genes nor y silvestres. Pesquisa Agropecuária Brasileira, v.40, p.41-46, 2005. DOI: http://dx.doi.org/10.1590/ S0100-204X2005000100006.

RODRÍGUEZ， G.R.; PRATTA， G.R.; LIBERATTI， D.R.; ZORZOLI, R.; PICARDI, L.A. Inheritance of shelf life and other quality traits of tomato fruit estimated from $\mathrm{F}_{1}$ 's, $\mathrm{F}_{2}$ 's and backcross generations derived from standard cultivar, nor homozygote and wild cherry tomato. Euphytica, v.176, p.137-147, 2010.

RODRÍGUEZ, G.R.; PRATTA, G.R.; ZORZOLI, R.; PICARDI, L.A. Evaluación de caracteres de planta y fruto en líneas recombinantes autofecundadas de tomate obtenidas por cruzamiento entre Lycopersicon esculentum y L. pimpinellifolium. Ciencia e Investigación Agraria, v.33, p.133-141, 2006a.

RODRÍGUEZ, G.R.; PRATTA, G.R.; ZORZOLI, R.; PICARDI, L.A. Recombinant lines obtained from an interspecific cross between Lycopersicon species selected by fruit weight and fruit shelf life. Journal of the American Society for Horticultural Science, v.131, p.651-656, 2006b. DOI: https://doi.org/10.21273/ JASHS.131.5.651.

RODRÍGUEZ, J.; ÁlVAREZ, M.; MOYA, C.; PLANA, D.; DUEÑAS, F.; LESCAY, E.; RODRÍGUEZ, S. Evaluación de la heterosis y heredabilidad en híbridos cubanos de tomate (Solanum lycopersicum). Cultivos Tropicales, v.29, p.63-68, 2008. 